\title{
PENGARUH DEWAN KOMISARIS INDEPENDEN TERHADAP NILAI PERUSAHAAN SUB SEKTOR PERKEBUNAN YANG TERDAFTAR DI BEI
}

\author{
Iroh Rahmawati \\ Universitas Banten Jaya \\ Serang, Indonesia \\ irohrahma@gmail.com
}

\begin{abstract}
Good corporate governance can signal the existence of harmonious interests between all stakeholders, thereby reducing conflict. In addition, company management can also achieve company goals, namely increasing company value. Firm value is the shareholder's perception of the company's success in managing its resources, which is reflected in the company's share price. This study aims to determine the effect of the independent board of commissioners on the company value of the plantatio sub-sector listed on the IDX. The population in this study were plantation sector companies listed on the Indonesia Stock Exchange in 2017-2018. Sampling was done by using purposive sampling, the sample used which met the standards is as many as 8 companies. The analysis used is a simple linear regression analysis by performing the classic assumption test, namely, normality test, multicollinearity, and autocorrelation. The results showed that the independent board of commissioners had an effect on firm value.
\end{abstract}

Kata kunci : Good Corporate Governance, Dewan Komisaris Independen, Nilai Perusahaan, agency theory.

\section{PENDAHULUAN}

Perusahaan adalah organisasi yang berfungsi sebagai pengelola sumber daya dalam menghasilkan produk dengan tujuan utamanya meningkatkan kesejahteraan dan memaksimalkan kekayaan pemegang saham. Memaksimalkan kekayaan pemegang saham dapat dilakukan salah satunya dengan cara meningkatkan nilai perusahaan. Pemegang saham lebih tertarik untuk berinvestasi ke perusahaan jika kemakmuran pemegang saham menunjukan nilai yang tinggi yang akan dapat meningkatkan nilai perusahaan (Thaharah \& Asyik, 2016).

Tata kelola perusahaan (Good Corporate Governance) yang baik memberikan sinyal adanya kepentingan selaras antara semua stakeholder sehingga dapat mengurangi konflik. Selain itu, manajemen perusahaan juga dapat mencapai tujuan perusahaan yaitu meningkatkan nilai perusahaan (Widuri, Wibowo, \& Yohananes, 2017). Nilai perusahaan merupakan persepsi pemegang saham terhadap pencapaian keberhasilan perusahaan dalam mengelola 
PROGRESS

Jurnal Pendidikan, Akuntansi dan Keuangan

Universitas Banten Jaya
Vol 4 No. 2, Agustus 2021

E-ISSN 2622-7037 |P-ISSN 2623-0763 sumber daya yang dimiliki yang tercermin dalam harga saham perusahaan tersebut (Saifi \& Hidayat, 2017). Nilai perusahaan dapat meningkat jika terdapat kerjasama yang baik antara manajemen perusahaan dengan komponen lain termasuk para pemegang saham, dan pemangku kepentingan dalam membuat keputusan keuangan dengan tujuan memaksimalkan modal.

Peningkatan nilai perusahaan dapat tercapai apabila terdapat kerja sama yang baik antara manajemen perusahaan dengan pihak lain yang meliputi shareholder maupun stakeholder. Dalam prakteknya penyatuan kepentingan antara manajemen dengan pemilik perusahaan seringkali menimbulkan masalah. Masalah antara manajer dan pemegang saham disebut masalah agensi (agency problem). Agency problem merupakan pemisahan antara kepemilikan (principal/investor) dan pengendalian (agent/manajer). Agency problem akan menyebabkan tidak tercapainya tujuan perusahaan, yaitu meningkatkan nilai perusahaan dengan cara memaksimumkan kekayaan pemegang saham. Diperlukan sebuah kontrol untuk monitoring dan pengawasan yang baik sehingga akan mengarahkan kepada tujuan sebagaimana mestinya yaitu nilai perusahaan semakin meningkat. Menurut Barnhart \& Rosenstein
(1998) dalam Purwantini (2011) mekanisme corporate governance terbagi menjadi dua yaitu internal mechanism (mekanisme internal) meliputi kepemilikan manajerial, dewan komisaris, ukuran dewan direksi, kepemilikan institusional, keberadaan komite audit dan dewan komisaris independen dan juga External mechanism (mekanisme eksternal), seperti pengendalian oleh pasar dan level debt financing. Penerapan corporate governance dapat meningkatkan pengawasan bagi perusahaan, sehingga melalui pengawasan diharapkan kinerja perusahaan akan lebih baik sehingga meningkatkan nilai perusahaan.

Peran penting kepemilikan institusi dapat mendorong peningkatan dan pengawasan kepada manajemen untuk lebih optimal, selain itu peran dewan komisaris independent dan komite audit tidak kalah penting dalam meningkatkan nilai perusahaan. Komisaris independen berfungsi untuk menjadi penyeimbangkan dalam pengambilan keputusan yaitu mempunyai anggota dewan komisaris yang berasal dari luar perusahaan (Kusumaningtyas \& Andayani, 2015).

Penerapan agensi teori dapat mengakibatkan hubungan yang asimetri antara pemilik dan pengelola perusahaan, untuk menghindari hal tersebut dibutuhkan 
PROGRESS

Jurnal Pendidikan, Akuntansi dan Keuangan

Universitas Banten Jaya
Vol 4 No. 2, Agustus 2021

E-ISSN 2622-7037 |P-ISSN 2623-0763 suatu konsep yaitu Good Corporate

Governance yang bertujuan untuk menjadikan perusahaan menjadi lebih sehat.

Penerapan corporate governance berdasarkan teori agensi, yaitu dapat menjelaskan hubungan antara manajemen dengan pemilik, manajemen sebagai agen secara moral bertanggung jawab dalam mengoptimalkan keuntungan para pemilik (principal), sebagai imbalannya manajemen akan memperoleh kompensasi yang sesuai dengan kontrak yang telah disepakati.

Terdapat dua kepentingan yang berbeda dalam perusahaan dimana masingmasing pihak berusaha untuk mencapai kemakmuran yang dikehendaki, sehingga timbul informasi asimetri antara manajemen dengan pemilik perusahaan yang dapat memberikan kesempatan kepada manajer untuk melakukan manajemen laba dalam rangka menyesatkan pemilik mengenai kinerja ekonomi perusahaan (Sefiana, 2009).

Menurut FCGI Dewan Komisaris merupakan bagian inti dari corporate governance yang bertugas untuk menjamin pelaksanaan strategi yang diterapkan oleh perusahaan, mengawasi manajemen dalam mengelola perusahaan, serta mewajibkan terlaksananya akuntabilitas dalam perusahaan.
Dewan komisaris merupakan suatu mekanisme untuk mengawasi dan memberikan petunjuk serta arahan bagi pengelola perusahaan. Dewan Komisaris memegang peran yang sangat penting bagi perusahaan, terutama dalam implementasi mekanisme corporate governance. Komisaris independen mempunyai fungi yaitu menjadi penyeimbang dalam mengambil keputusan yang beranggotakan dewan komisaris yang berasal dari luar perusahaan (Kusumaningtyas \& Andayani, 2015).

Nilai perusahaan bisa dilambangkan dengan price to book value (PBV), merupakan tingkat kepercayaan pasar pada prospek perusahaan ke depan (Euis dan Taswan, 2002). Rasio harga saham terhadap nilai buku perusahaan atau price book value (PBV), melambangkan tingkat kemampuan perusahaan dalam menciptakan nilai relatif terhadap jumlah modal yang diinvestasikan. PBV yang tinggi mencerminkan harga saham yang tinggi dibandingkan nilai buku perlembar saham. Tandellin (2001) menyebutkan hubungan antara harga pasar dan nilai buku per lembar saham bisa juga dipakai sebagai pendekatan alternatif untuk menentukan nilai suatu saham, karena secara teoritis nilai pasar suatu saham haruslah mencerminkan nilai bukunya. (Zanera, Fifi, dan Widyar:2013) 
Penelitian-penelitian sebelumnya tentang variabel-variabel yang berpengaruh terhadap nilai perusahaan masih mengalami hasil yang berbeda (inkonsisten). Thaharah \& Asyik (2016) dan Saifi \& Hidayat (2017) menemukan hasil yaitu dewan komisaris independen berpengaruh terhadap nilai perusahaan. Hasil penelitian tersebut tidak sama hasilnya dengan penelitian yang dilakukan oleh Kusumaningtyas \& Andayani
(2015), Amrizal (2016) dan Veronica (2013) yang memberikan hasil bahwa dewan komisaris independen tidak berpengaruh secara signifikan terhadap nilai perusahaan.

Penelitian ini bertujuan untuk mengetahui apakah dewan komisaris independen berpengaruh terhadap nilai perusahaan yang merujuk kepada agency theory.

\section{Model Penelitian}

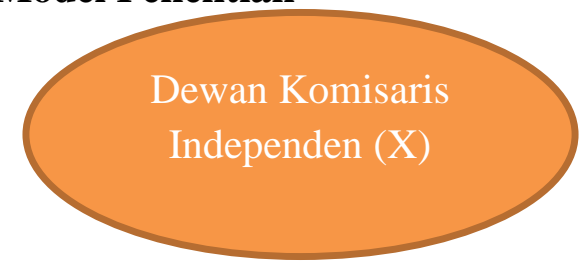

Pengaruh Dewan Komisaris Independen Terhadap Nilai Perusahaan Dewan komisaris merupakan dewan yang bertugas untuk melakukan pengawasan kegiatan perusahaan. Keberadaan dewan komisaris independen menjadi sangat penting karena dalam praktiknya sering ditemukan transaksi yang mengandung unsure perbedaan kepentingan dalam perusahaan publik. Komisaris independen memiliki tanggung jawab untuk mendorong diimplementasikannya prinsip tata kelola perusahaan yang baik.
Nilai Perusahaan

(Y)

Menurut teori keagenan (Jensen \& Meckling, 1976), dewan komisaris independen dianggap sebagai mekanisme pengendalian intern tertinggi yang bertanggung jawab untuk memonitor kebijakan manajemen puncak. Menurut teori keagenanan menyatakan bahwa banyaknya anggota dewan komisaris independen dapat mempermudah dalam mengendalikan manajemen puncak, dan dapat meningkatkan fungsi monitoring sehingga nilai perusahaan naik. Penelitian yang dilakukan (Thaharah \& Asyik, 2016) dan (Saifi \& Hidayat, 2017) menyimpulkan bahwa dewan komisaris independen berpengaruh positif terhadap 
nilai perusahaan. Sedangkan menurut (Amrizal, 2016) dan (Veronica, 2013) serta (Aryanto \& Setyorini, 2019) dewan komisaris independen tidak memberikan pengaruh signifikan terhadap nilai perusahaan. Berdasarkan teori dan hasil penelitian terdahulu maka hipotesis yang diajukan adalah:

H1 : Dewan komisaris independen berpengaruh positif terhadap nilai perusahaan.

\section{METODE PENELITIAN}

Penelitian ini merupakan penelitian kuantitatif dengan melakukan studi empiris pada perusahaan yang terdaftar di Bursa Efek Indonesia (BEI) khususnya perusahaan sector perkebunan selama tahun 2015-2018. Penelitian kuantitatif dapat diartikan sebagai metode penelitian yang berlandasan positivisme yang digunakan untuk meneliti populasi atau sampel tertentu yang bertujuan untuk menguji hipotesis yang telah ditetapkan (Sugiyono, 2014)

Populasi dalam penelitian ini adalah perusahaan sektor perkebunan yang terdaftar di Bursa Efek Indonesia tahun 2015-2018. Pengambilan sampel dilakukan dengan menggunakan purposive sampling dengan tujuan mendapatkan sampel yang sesuai dengan kriteria yang ditentukan, yaitu:

1. Perusahaan sektor perkebunan yang terdaftar di Bursa Efek Indonesia periode tahun 2015-2018.

2. Perusahaan sektor perkebunan menyediakan laporan tahunan lengkap yang sudah diaudit periode tahun 2015-2018.

3. Perusahaan yang memiliki informasi data lengkap sesuai dengan variabelvariabel yang diteliti

\section{Tabel 1. Jumlah sampel perusahaan}

\begin{tabular}{lc}
\hline \multicolumn{1}{c}{ Keterangan } & Jumlah \\
\hline Perusahaan perkebunan yang terdaftar 2015-2018 & 18 \\
Data yang tidak berhasil diperoleh secara fisik baik di BEI maupun & $(6)$ \\
website perusahaan & 12 \\
Data yang tersedia secara fisik & $(4)$ \\
Perusahaan yang tidak menginformasikan variable terkait & 8 \\
\hline Jumlah data yang digunakan sebagai sampel &
\end{tabular}

Sumber: Laporan Tahunan Perusahaan Perkebunan 2015-2018 
PROGRESS

Jurnal Pendidikan, Akuntansi dan Keuangan

Universitas Banten Jaya
Vol 4 No. 2, Agustus 2021

E-ISSN 2622-7037 |P-ISSN 2623-0763

\section{Operasional Variabel}

Variabel dalam penelitian ini adalah dewan komisaris independen sebagai variable independen dan nilai perusahaan sebagai variable dependen. Definisi operasional variabel dapat dilihat pada tabel berikut ini :

Tabel 2. Definisi Operasional Variabel

\begin{tabular}{|c|c|c|c|}
\hline $\begin{array}{l}\mathbf{N} \\
\mathbf{0}\end{array}$ & Variabel Penelitian & Definisi Operasional & Indikator \\
\hline 1 & $\begin{array}{l}\text { Dewan Komisaris } \\
\text { Independen }\end{array}$ & $\begin{array}{l}\text { Komisaris independen merupakan salah } \\
\text { satu faktor yang dapat mempengaruhi } \\
\text { kinerja perusahaan. Semakin besar } \\
\text { ukuran komisaris independen, semakin } \\
\text { efektif pula proses monitor serta } \\
\text { pelaporan keuangan. (Rafriny, 2012). }\end{array}$ & $\begin{array}{l}\text { Rasio dewan komisaris independen dalam } \\
\text { penelitian ini dinyatakan dengan } \\
\text { perbandingan jumlah anggota dewan } \\
\text { komisaris independen dengan total dewan } \\
\text { komisaris (Yudha, dkk 2014). } \\
\mathrm{KI}=\frac{\text { KKomisaris Independen }}{\text { Total jumlah anggota dewan komisaris }}\end{array}$ \\
\hline 2 & Nilai Perusahaan & $\begin{array}{l}\text { Nilai perusahaan lazim diindikasikan } \\
\text { dengan price to book value (PBV), yang } \\
\text { merupakan tingkat kepercayaan pasar } \\
\text { pada prospek perusahaan ke depan } \\
\text { (Euis dan Taswan, 2002). }\end{array}$ & $\begin{array}{l}\text { Proksi yang digunakan untuk mengukur } \\
\text { nilai perusahaan adalah Price Book Value } \\
\text { (PBV).Dapat } \\
\text { dihitung menggunakan rumus: } \\
\text { PBV }=\frac{\text { Harga pasar per Lembar }}{\text { Nilai buku per lembar saham }}\end{array}$ \\
\hline
\end{tabular}

Sumber : Dikelola oleh Peneliti 2020

HASIL PENELITIAN DAN deviasi dari satu variabel dependen yaitu nilai

\section{PEMBAHASAN}

\section{Statistik Deskriptif}

Hasil analisis statistik deskriptif dalam

penelitian ini meliputi nilai minimum, maksimum, mean (rata-rata), dan standar perusahaan dan variabel independen yaitu dewan komisaris independen adalah sebagai berikut:

Tabel 3. Hasil Statistik Deskriptif

\begin{tabular}{lrrrrr}
\hline & \multicolumn{4}{c}{ Descriptive Statistics } & \\
& $N$ & Minimum & \multicolumn{1}{c}{ Maximum } & Mean & \multicolumn{1}{c}{ Std. Deviation } \\
\hline DKI & 32 &, 50 & 4,00 & 1,2019 &, 88175 \\
Nilai Perusahaan & 32 & 304,00 & 158252284,00 & 5789718,5312 & 27846414,58756 \\
Valid N (listwise) & 32 & & & & \\
\hline
\end{tabular}

Sumber : Output SPSS 
Dari tabel uji statistik deskriptif diatas dapat diketahui bahwa nilai mean dari dewan komisaris independent (DKI) 1,2019, standar deviasi sebesar 0,88175 dan nilai mean untuk variable nilai perusahaan (NP) adalah sebesar 5789718,5312 dan standar deviasi sebesar 27846414,58756. Standar deviasi dengan nilai lebih kecil dibandingkan nilai rata-rata menunjukkan bahwa rendahnya simpangan data variabel dewan komisaris dan nilai perusahaan selama periode pengamatan.

\section{Uji Asumsi Klasik}

\section{Uji Normalitas}

Tabel.4

One-Sample Kolmogorov-Smirnov Test

\begin{tabular}{llr}
\hline & & $\begin{array}{c}\text { Unstandardized } \\
\text { Residual }\end{array}$ \\
\hline $\mathrm{N}$ & Mean & 32 \\
Normal Parameters $^{\mathrm{a}, \mathrm{b}}$ & Std. Deviation &, 0000000 \\
& & 169 \\
Most Extreme Differences & Absolute &, 313 \\
& Positive &, 313 \\
& Negative &,- 306 \\
Test Statistic & &, 313 \\
Asymp. Sig. (2-tailed) & &, 412 \\
a. Test distribution is Normal. & \\
b. Calculated from data. & \\
c. Lilliefors Significance Correction. & \\
\hline
\end{tabular}

Sumber : Output SPSS

Uji normalitas adalah sebuah uji yang dilakukan untuk menguji apakah nilai residual yang telah distandarisasi memiliki distribusi normal (Suliyanto, 2011).

Berdasarkan hasil uji Kolmogorov Smirnov pada tabel diatas menunjukkan bahwa nilai sig. sebesar $0,412>0,05$. Artinya nilai residual terstandarisasi dapat dinyatakan menyebar secara normal.

\section{Uji Multikolinieritas}

Uji multikolinieritas bertujuan untuk mengetahui adanya korelasi antara variabel independen dengan melihat nilai tolerance dan Variance Infaltion Factor (VIF). Nilai cut off yang umum dipakai untuk menunjukkan adanya multikolinieritas adalah nilai tolerance 0.10 dan nilai VIF < 10 (Ghozali, 2018). Berdasarkan output SPSS dapat ditentukkan besarnya VIF dan nilai tolerance dari masing- 
masing variabel independen. Hasil tersebut dapat terlihat pada tabel 5 sebagai berikut:

\section{Tabel 5 Hasil Uji Multikolinieritas}

\begin{tabular}{|c|c|c|c|c|c|c|c|}
\hline \multicolumn{8}{|c|}{ Coefficients $^{\mathrm{a}}$} \\
\hline \multirow[b]{2}{*}{ Model } & \multicolumn{2}{|c|}{ Unstandardized Coefficients } & \multicolumn{3}{|l|}{$\begin{array}{l}\text { Standardized } \\
\text { Coefficients }\end{array}$} & \multicolumn{2}{|c|}{ Collinearity Statistics } \\
\hline & B & Std. Error & Beta & $\mathrm{t}$ & Sig. & Tolerance & VIF \\
\hline \multirow{2}{*}{$\begin{array}{ll}1 & \text { (Constant) } \\
& \text { DKI }\end{array}$} & $-15935102,409$ & 7009040,410 & & $-2,274$ &, 030 & & \\
\hline & 18075774,054 & 4727972,886 &, 572 & 3,823 & 001 & 1,000 & 1,320 \\
\hline \multicolumn{8}{|c|}{ a. Dependent Variable: Nilai Perusahaan } \\
\hline
\end{tabular}

Sumber : Output SPSS

Hasil uji multikolinieritas terdapat pada tabel 5yang menunjukkan bahwa tidak ada variabel independen yang memiliki nilai tolerance kurang dari 0.10 yang berarti tidak ada korelasi antar variabel independen yang nilainya lebih besar dari 54 95\%. Hasil perhitungan untuk Variance Infaltion Factor (VIF) juga menunjukkan nilai VIF variabel independen yaitu dewan komisaris independen tidak lebih dari 10, dengan demikian dapat disimpulkan bahwa tidak ada multikolinieritas yang terjadi antar variable independen dalam model regresi.

\section{Uji Autokorelasi}

Uji Autokorelasi dalam penelitian ini menggunakan uji Durbin Watson. Hasil dari Uji Autokorelasi adalah sebagai berikut :

Tabel.6 Durbin Watson.

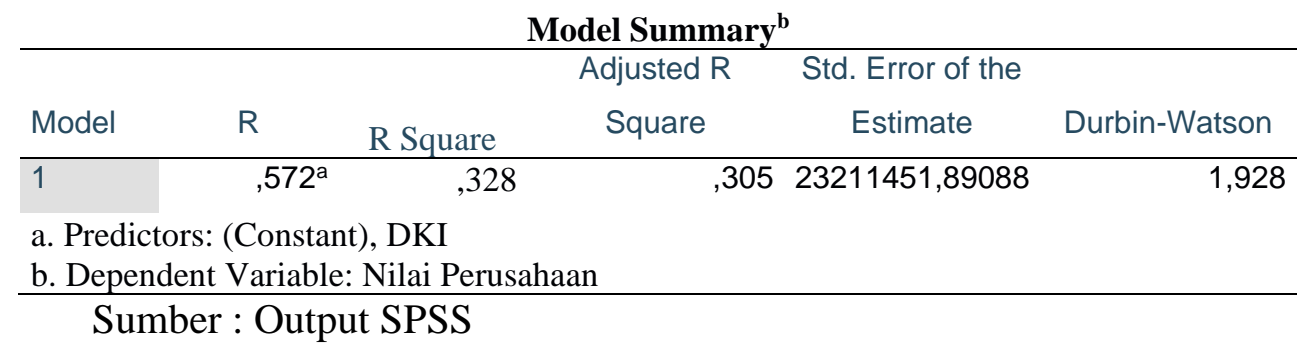

Dari uji autokolerasi menunjukkan nilai Durbin Watson sebesar 1,928. Nilai tersebut dibandingkan dengan nilai tabel Durbin Watson dengan menggunakan tingkat signifikansi $0,05(\alpha=5 \%)$, jumlah variable bebas $1(\mathrm{k}=1)$, dan jumlah data sampel 32 $(\mathrm{n}=32)$. Diperoleh nilai $\mathrm{dL}=1,373$ dan
$\mathrm{dU}=1,501$, karena nilai DW sebesar 1,928 > dU $(1,501)$ yang berarti bahwa dalam model regresi tidak terdapat autokolerasi.

\section{Hasil Pengujian Regresi}

Hipotesis dalam penelitian ini diuji dengan menggunakan metode regresi linier 
sederhana yang digunakan untuk menguji pengaruh variable independen terhadap satu variabel dependen. Selanjutnya untuk mendukung hipotesis dalam penelitian ini maka akan dilanjutkan uji t, dan koefisien determinasi. Hasil analisis regresi linier sederhana pada penelitian ini adalah sebagai berikut :

Tabel. 7 Analisis Regresi Linier Sederhana

\begin{tabular}{|c|c|c|c|c|c|c|}
\hline \multicolumn{7}{|c|}{ Coefficients $^{a}$} \\
\hline & & \multirow{2}{*}{\multicolumn{2}{|c|}{ Unstandardized Coefficients }} & \multirow{2}{*}{$\begin{array}{l}\text { Standardized } \\
\text { Coefficients }\end{array}$} & \multirow[b]{3}{*}{$\mathrm{t}$} & \multirow[b]{3}{*}{ Sig. } \\
\hline & & & & & & \\
\hline \multicolumn{2}{|l|}{ Model } & $\mathrm{B}$ & Std. Error & Beta & & \\
\hline \multirow[t]{2}{*}{1} & (Constant) & $-15935102,409$ & 7009040,410 & & $-2,274$ &, 030 \\
\hline & DKI & 18075774,054 & 4727972,886 &, 572 & 3,823 & ,001 \\
\hline
\end{tabular}

a. Dependent Variable: Nilai Perusahaan

$\mathrm{a}=$ angka konstanta dari unstandardized coefficients. Dar tabel diatas nilainya sebebsar 15,409. Angka ini merupakan konstanta yang artinya jika ada Dewan Komisaris Independen (X) maka nilai konstanta Nilai Perusahaan (Y) adalah sebesar 15,409. Sedangkan nilai $b=$ angka koefisien regresi. Nilainya sebesar $-8,054$, hal ini berarti bahwa setiap penambahan $1 \%$ dewan komisasris independent (X), maka nilai perusahaan akan meningkat sebesar 8,054 .

Dari tabel diatas dapat diketahui persamaan regresi adalah sebagai berikut : Y $=15,409-8,054$, sehingga dapat dikatakan bahwa dewan komisaris independen berpengaruh negative terhadap nilai perusahaan.
Sementara untuk menguji hipotesis dengan cara membandingkan nilai signifkansi (Sig) dengan probabilitas 0,05, atau dengan membadingkan antara $\mathrm{t}$ hitung dengan $\mathrm{t}$ tabel. Berdasarkan output di atas diketahui bahwa nilai signifikansi (Sig) sebesar 0,001 lebih kecil dari < probabilitas 0,05 sehigga dapat dikatakan bahwa H0 ditolak dan $\mathrm{Ha}$ diterima, artinya terdapat pengaruh dewan komisaris independent terhadap nilai perusahaan. Hal ini sejalan dengan peelitian yang dilakukan oleh (Thaharah \& Asyik, 2016) dan (Saifi \& Hidayat, 2017) menyimpulkan bahwa dewan komisaris independen berpengaruh positif terhadap nilai perusahaan.

Menurut teori keagenan (Jensen \& Meckling, 1976), dewan komisaris independen dianggap sebagai mekanisme 
PROGRESS

Jurnal Pendidikan, Akuntansi dan Keuangan

Universitas Banten Jaya
Vol 4 No. 2, Agustus 2021

E-ISSN 2622-7037 |P-ISSN 2623-0763 pengendalian intern tertinggi yang bertanggung jawab untuk memonitor kebijakan manajemen puncak. Menurut teori keagenanan menyatakan bahwa banyaknya anggota dewan komisaris independen dapat mempermudah dalam mengendalikan manajemen puncak, dan dapat meningkatkan fungsi monitoring sehingga nilai perusahaan naik.

\section{KESIMPULAN DAN SARAN}

\section{Kesimpulan}

Hasil perhitungan menunjukan bahwa nilai signifikansi (Sig) sebesar 0,001 lebih kecil dari < probabilitas 0,05 sehigga dapat dikatakan bahwa H0 ditolak dan Ha diterima, artinya terdapat pengaruh dewan komisaris independent terhadap nilai perusahaan. Hal ini sejalan dengan penelitian yang dilakukan oleh (Thaharah \& Asyik, 2016) dan (Saifi \& Hidayat, 2017) menyimpulkan bahwa dewan komisaris independen berpengaruh positif terhadap nilai perusahaan.

\section{Saran}

1. Variabel penelitian yang digunakan dapat diperluas seperti komite audit, ukuran perusahaan, dan menggunakan data penelitian dengan periode yang lebih lama.

2. Bagi para investor yang akan berinvestasi pada perusahaan yang terdaftar di BEI sebaiknya melihat tingkat kepemilikan manajerial, karena semakin besar nilai kepemilikikan manajerial maka nilai perusahaanpun akan semakin meningkat.

3. Sebaiknya penerapan good corporate governance diterapkan dengan baik untuk meningkatkan nilai perusahaan, bukan hanya sekedar ematuhi ketentuan peraturan yang berlaku.

\section{DAFTAR PUSTAKA}

Amrizal, S. H. N. R. (2016). Pengaruh Kepemilikan Institusional, Dewan Komisaris Independen, Kualitas Audit, Komite Audit terhadap Nilai Perusahaan. Jurnal Akuntansi STIE Ahmad Dahlan Jakarta, 4(1), 76-89. Aryanto, A., \& Setyorini, C. T. (2019). Pengaruh Tata Kelola Perusahaan Dan Tanggung Jawab Sosial Terhadap Nilai Perusahaan Sektor Pertambangan. Jurnal Informasi, Perpajakan, Akuntansi, Dan Keuangan Publik, 14(2), 181.

Amyulianthy, Rafriny. (2012). Pengaruh Struktur Corporate Governance Terhadap Kinerja Perusahaan Publik Indonesia. Liquidity, 1, 91-98.

Barnhart, Scott W. Dan Stuart Rosenstein. (1998). Board composition, managerial ownership, and firm performance: An empirical analysis. The Financial Review. 33 (November).(4).1-16.

Jensen, Michael C And William H. Meckling. 1976. Theory of the Firm: Managerial Behavior, Agency Costs and Ownership Structure. Journal Of Financial Economic volume 3 No 4. No. 4, pp. 305-360. 
PROGRESS

Jurnal Pendidikan, Akuntansi dan Keuangan

Universitas Banten Jaya
Vol 4 No. 2, Agustus 2021

E-ISSN 2622-7037 |P-ISSN 2623-0763
Kusumaningtyas, T. K., \& Andayani. (2015).

Pengaruh Good Corporate

Governance terhadap Nilai

Perusahaan yang Terdaftar pada Iindeks Sri-Kehati. Jurnal Ilmu \& Riset Akuntansi,4(7).

Laurensia \& Yeterina, Pengaruh Struktur Kepemilikan dan Dewan Komisaris Independen Terhadap Nilai Perusahaan (Studi Pada Perusahaan Industri Barang Konsumsi di BEI Tahun 2011-2013). KInerja, Volume 18 No 1 Tahun 2014, Hal 64-80.

Purwantini, V. T., 2011, Pengaruh Mekanisme Good Corporate Governance terhadap Nilai Perusahaan dan Kinerja Keuangan Perusahaan yang terdaftar di Bursa Efek Indonesia, Jurnal Ekonomi Bisnis dan Perbankan, 19.

Saifi, M. C. S. T. M., \& Hidayat, R. R. (2017). Pengaruh Good Corporate Governance terhadap

Nilai Perusahaan (Studi pada Perusahaan Sub Sektor Food and Beverages yang Terdaftar di BEI Tahun 2012-2015) Mei. EProceeding of Management, 4(3), 2261-2266.

Solihah, Euis dan Taswan, (2002). Pengaruh Kebijakan Hutang Terhadap Nilai Perusahaan Serta Beberapa Faktor Yang Mempengaruhinya. Jurnal Bisnis dan Ekonomi.

Sugiyono. (2014). Metode Penelitian Bisnis (Pendekatan Kuantitatif \& Kualitatif). Bandung: CV. Alfabeta
Suliyanto. (2011). Ekonometrika Terapan Teori dan Aplikasi dengan SPSS. Yogyakarta: Penerbit ANDI.

Tandelilin, Eduardus. 2010. Portofolio dan Investasi. Yogyakarta: Kanisius

Thaharah \& Asyik. (2016). Pengaruh Mekanisme Corporate Governance Dan Kinerja Keuangan Terhadap Nilai Perusahaan LQ 45. Jurnal Ilmu Dan Riset Akuntansi, 5(2), 1-18. https://doi.org/ISSN : 2460-0585

www.idx.co.id

Veronica, wardoyo \& theodora martina. (2013). pengaruh good corporate governance, CSR dan Kinerja keuangan terhadap nilai perusahaan. Jurnal Dinamika Manajemen, 4(2), 132-149. Retrieved from http://journal.unnes.ac.id/nju/index.p $\mathrm{hp} / \mathrm{jdm}$

Widuri, K., Wibowo, B. J., \& Yohananes. (2017). The Mediating Effect of Corporate Social Responsibility and Corporate Governanceon the Company' s Firm Value. Research Journal of Social Sciences, 10(3), 1-7 Yudha, Latifah dan Adi Prasetyo. (2014).“ Pengaruh Corporate Governance Terhadap Kinerja Keuangan Perusahaan Manufaktur yang Go Public di BEI". Jurnal Ekonomi Universitas Muhamadiyah Malang

Zanera, Fifi, \& Widyar, (2013). Pengaruh Mekanisme Good Corporate Governance (GCG) Pada Nilai Perusahaan (Studi Pada Perusahaan Yang Masuk Indeks LQ45 di Bursa Efek Indonesia).Hal 407-423 
PROGRESS

Jurnal Pendidikan, Akuntansi dan Keuangan

Universitas Banten Jaya
Vol 4 No. 2, Agustus 2021

E-ISSN 2622-7037 |P-ISSN 2623-0763 